\title{
Application of the MISSCARE scale in an Oncology Service: a contribution to patient safety
}

\author{
Aplicação da escala MISSCARE em um Serviço de Oncologia: uma contribuição à segurança \\ do paciente \\ Aplicación de la escala MISSCARE en un Servicio de Oncología: una contribución a la seguridad \\ del paciente
}

How to cite this article:

Rabin EG, Silva CN, Souza AB, Lora PS, Viegas K. Application of the MISSCARE scale in an Oncology Service: a contribution to patient safety. Rev EsC Enferm USP. 2019;53:e03513. DOI: http://dx.doi.org/10.1590/S1980-220X2018025403513

\section{Eliane Goldberg Rabin ${ }^{1}$ \\ Camila Neves da Silva ${ }^{2}$ \\ Aline Brenner de Souza ${ }^{3}$ \\ Priscila Schmidt Lora ${ }^{4}$ \\ Karin Viegas ${ }^{5}$}

${ }^{1}$ Universidade Federal de Ciências da Saúde, Department of Nursing, Coordinator of Multidisciplinary Residency Program in Oncohematology, Porto Alegre, RS, Brazil.

${ }^{2}$ Irmandade Santa Casa de Misericórdia, Hospital Santa Rita, Porto Alegre, RS, Brazil.

${ }^{3}$ Hospital Moinhos de Vento, Quality and Safety Coordination, Porto Alegre, RS, Brazil.

${ }^{4}$ Universidade do Vale do Rio dos

Sinos, Graduate Program in Nursing,

Porto Alegre, RS, Brazil.

${ }^{5}$ Universidade Federal de Ciências

da Saúde, Graduate Program in

Nursing, Porto Alegre, RS, Brazil.

\begin{abstract}
Objective: To investigate the prevalence of and reasons for missed nursing care in oncology units. Method: A cross-sectional study was conducted at inpatient oncology units at a private hospital. Eighty-three professionals from the nursing team took part. The MISSCARE instrument and a sociodemographic questionnaire were administered. Simple descriptive statistics were used for analyses. Pearson's chi-square test was used to detect associations between variables. Results: The care tasks missed most frequently were assisting with toileting needs within 5 minutes of a request $(57.8 \%)$, ambulation 3 times per day or as ordered (44.6\%), and turning patients every 2 hours (36.1\%). The main reasons for missed care were related to communication: tension or communication breakdowns within the nursing team, and the caregiver responsible off unit or unavailable (both 66.2\%). Conclusions: there is a need to develop nursing interventions that neutralize and/or reduce the negative results of this missed care in order to improve the quality of care provided to cancer patients.
\end{abstract}

\section{DESCRIPTORS}

Oncology Service, Hospital; Nursing Care; Oncology Nursing; Quality of Health Care; Patient Safety. 


\section{INTRODUCTION}

The subject of patient safety and provision of safe care is gaining ever greater importance for patients and their families and health professionals and managers. Globally, healthcare system records reveal elevated rates of morbidity and mortality caused by incidents associated with healthcare and, in particular, by adverse events (incidents involving patient harm), leading the World Health Organization and a variety of international organizations to launch campaigns, challenges, and strategies aimed to reduce risk and harm in healthcare ${ }^{(1-2)}$. Current estimates identify medical errors as the third-ranked cause of deaths in the United States. In England, it has been estimated that there is one incident per patient every 35 seconds $^{(2)}$. In developing countries, there are many unfavorable factors that contribute to reduce patient safety, such as overcrowded health services, insufficient staff, inadequate infrastructure, and poor sanitary and hygiene conditions ${ }^{(3)}$.

Safety of care provision can be considered one of the indicators with greatest impact on quality of health services, since it is not possible to deliver high quality care if it is not provided safely. It is therefore the duty of every healthcare institution to reduce the probability of patient harm caused by provision of care $^{(4)}$.

Analysis of indicators is one strategy for ensuring care safety and for controlling healthcare quality results. By using healthcare indicators, standards can be set and monitored by both healthcare professionals and their clients ${ }^{(5)}$.

Institutions that provide care for cancer patients tend to be a focus of management attention, in all settings, because of the high cost of treatments and the duration of inpatient stays. Taken together, all of these elements indicate the need for increased efficiency and quality in provision of services, which in turn will influence prevention, detection, and correct management of complications ${ }^{(6)}$.

One potential source of variation in the quality of day to day care is missed nursing care, which, conceptually, is considered an error of omission and, operationally, is defined as any aspect of patient care that is omitted (in part or in its entirety) or delayed significantly ${ }^{(6-7)}$.

The importance of using an instrument specifically developed to assess the phenomenon of missed nursing care lies in the fact that it identifies acts of omission that could result in negative consequences for patient care and also identifies the circumstances in which these care tasks are missed $^{(8-9)}$.

Missed nursing care tasks are a phenomenon that can threaten patient safety in all countries and cultures with a direct impact on the quality of care provision. However, there are few international and, particularly, Brazilian studies that have analyzed and quantified these omissions in hospital settings, especially oncology units. The objective of this study was therefore to determine the prevalence and the reasons for missed nursing care in inpatient oncology units at a private hospital in Brazil.

\section{METHOD}

\section{Study Design}

A cross-sectional study was conducted in three inpatient oncology units at a large private hospital.

\section{Study POPULATION}

The study population comprised nursing professionals from all three shifts. Exclusion criteria: professionals with less than 6 months experience in oncology nursing were excluded as were nurses who were on holiday or absent from work for health-related reasons. The study sample was therefore non-probabilistic, comprising 83 participants.

\section{Data ColleCtion}

Data collection took place from May to August 2017. Data were collected using two self-reported instruments. A sociodemographic questionnaire was administered first, in order to delineate the profile of the participants, and then the MISSCARE instrument was administered to assess missed nursing care tasks. The MISSCARE questionnaire has 41 items, divided into two parts (A and B). Part A comprises 24 items divided across four dimensions: Dimension 1 - discharge planning and patient education; Dimension 2 - interventions for individual needs; Dimension 3 - interventions for basic care; and Dimension 4 - continuous assessments. Each item has a response scale varying from 'Always missed' (1); through 'Frequently missed' (2), 'Occasionally missed' (3), and 'Rarely missed'(4), to 'Never missed'(5). Values 1, 2, and 3 were defined as omission. Part B comprises 17 items related to reasons for not providing the care items. Response options vary from Significant reason (1), through Moderate reason (2), and Minor reason (3), Not a reason for missed care (4). Values 1 and 2, were defined as reasons for missed care. The instruments were administered in a private room at the workplace, preserving participants' confidentiality and anonymity.

\section{ANALYSIS AND PROCESSING DATA}

The data collected were inserted in Microsoft Excel and later transferred and analyzed using SPSS (Statistical Package for the Social Sciences; version 22.0) for Windows. Internal consistency of the instrument was validated using Cronbach's Alpha. Simple descriptive statistics means and standard deviations were used for analyses. Pearson's chi-square test was used to test associations between study variables, considering a 95\% confidence interval and $p<0.05$.

\section{ETHICAL ASPECTS}

The ethical principles enshrined in the Brazilian National Health Council's Resolution 466/12 on research involving human beings were adhered to ${ }^{(10)}$. Participants were informed of the study objectives and invited to take part and signed free and informed consent forms. The research protocol was approved by the local Research Ethics Committee, under protocol number 2.022.254 of 2017. All 
procedures were in accordance with the ethical standards of the Helsinki declaration and its later amendments or comparable ethical standards.

\section{RESULTS}

Among the study participants, $83.1 \%$ were nursing technicians, $16.9 \%$ were nurses, and females predominated (90.4\%). The professionals' ages ranged from 22 to 56 years (mean: $33.7 \pm 7.1$ ). Regarding academic qualifications, technical qualifications predominated (81.9\%), followed by $12 \%$ with postgraduate diplomas and $6 \%$ with bachelor's degrees.

Experience working in an oncology setting varied from 6 months to 27 years, with a mean of 1.4 years. Cronbach's Alpha for the instrument's internal consistency was 0.927 , which is considered a reliable value for this sample.

Table 1 lists the sociodemographic data and their relationships with each dimension in Part A of the MISSCARE instrument. There were statistically significant associations in Dimension 3 with role $(\mathrm{p}=0.010)$, academic qualifications $(p=0.018)$, and experience $(p=0.046)$.

Table 1 - Dimensions of Part A of the MISSCARE instrument, by sociodemographic data of nursing professionals - Porto Alegre, RS, Brazil, 2017.

\begin{tabular}{|c|c|c|c|c|}
\hline \multirow{2}{*}{ Variables } & \multicolumn{4}{|c|}{ Dimensions* } \\
\hline & Dimension 1 & Dimension 2 & Dimension 3 & Dimension 4 \\
\hline Role & 0.354 & 0.178 & 0.010 & 0.255 \\
\hline Academic qualifications & 0.284 & 0.399 & 0.018 & 0.683 \\
\hline Experience & 0.603 & 0.082 & 0.046 & 0.058 \\
\hline Time (years) in role & 0.986 & 0.557 & 0.255 & 0.342 \\
\hline
\end{tabular}

$* \mathrm{p}=$ Pearson's chi-square.

Of the missed care dimensions, it was observed that only Dimension 2 was lower than ideal $(3.90 \pm 0.35)$. The care items most often missed (scored as always missed, frequently missed, or occasionally missed) by the nursing professionals were assisting with toileting needs within 5 minutes of request (57.8\%), ambulation 3 times per day or as ordered (44.6\%), turning the patient every 2 hours (36.1\%), and administering medications within 30 minutes before or after scheduled time (36.1\%) (Table 2).

Table 2 - Assessment of missed care items in each dimension of the MISSCARE instrument - Porto Alegre, RS, Brazil, 2017.

\begin{tabular}{|c|c|}
\hline Missed care items by dimension & Mean \pm Standard deviation* \\
\hline \multicolumn{2}{|l|}{ Dimension 1} \\
\hline Full documentation of all necessary data & $4.43 \pm 0.802$ \\
\hline IV/central line site care and assessments according to hospital policy & $4.55 \pm 0.740$ \\
\hline Monitoring fluid balance - Intake/output & $4.54 \pm 0.804$ \\
\hline Vital signs assessed as ordered & $4.39 \pm 0.857$ \\
\hline Focused reassessments according to patient condition & $4.45 \pm 0.932$ \\
\hline Hand washing & $4.63 \pm 0.729$ \\
\hline Capillary glucose monitoring & $4.71 \pm 0.676$ \\
\hline Patient assessments performed each shift & $4.65 \pm 0.760$ \\
\hline Total for Dimension 1 & $4.54 \pm 0.11$ \\
\hline \multicolumn{2}{|l|}{ Dimension 2} \\
\hline Assess effectiveness of medications & $4.15 \pm 0.918$ \\
\hline PRN medication requests acted on within 15 minutes & $3.87 \pm 0.872$ \\
\hline Medications administered within 30 minutes before or after scheduled time & $3.82 \pm 0.818$ \\
\hline Assist with toileting needs within 5 minutes of request & $3.29 \pm 0.896$ \\
\hline Response to patient call within 5 minutes & $3.94 \pm 0.807$ \\
\hline Emotional support to patient and/or family & $4.32 \pm 0.887$ \\
\hline Total for Dimension 2 & $3.90 \pm 0.35$ \\
\hline
\end{tabular}




\begin{tabular}{|c|c|}
\hline Missed care items by dimension & Mean \pm Standard deviation* \\
\hline \multicolumn{2}{|l|}{ Dimension 3} \\
\hline Ambulation 3 times per day or as ordered & $3.52 \pm 1.146$ \\
\hline Turning patient every 2 hours & $3.72 \pm 0.850$ \\
\hline Mouth care & $3.98 \pm 0.875$ \\
\hline Feeding patient when the food is still warm & $3.88 \pm 0.807$ \\
\hline Patient bathing/skin care & $4.35 \pm 0.807$ \\
\hline Setting up meals for patients who feed themselves & $4.34 \pm 0.789$ \\
\hline Skin/wound care & $4.27 \pm 0.876$ \\
\hline Total for Dimension 3 & $4.01 \pm 0.32$ \\
\hline Patient teaching about procedures, tests, and other diagnostic studies & $3.87 \pm 0.991$ \\
\hline Attend interdisciplinary care conference whenever held & $3.84 \pm 1.160$ \\
\hline Patient discharge planning and teaching & $4.41 \pm 0.785$ \\
\hline Total for Dimension 4 & $4.04 \pm 0.32$ \\
\hline
\end{tabular}

* Scores: 1 (always missed), 2 (frequently missed), 3 (occasionally missed), 4 (rarely missed), or 5 (never missed).

The main factors that impact on missed nursing care are divided into three dimensions: communication, labor resources, and material resources. Reasons for missed care in the communication category were the most prevalent. Of these, the most often cited reasons were: tension or communication breakdowns within the nursing team and caregiver responsible off unit or unavailable, both cited by $66.2 \%$. Additionally, $60.2 \%$ indicated as reasons for missed care a lack of back up support from team members and other professionals not providing the care needed (e.g. physiotherapist did not ambulate patient) (Table 3 ).

Table 3 - Mean and standard deviation of main reasons for missed care in the dimensions communication, human resources, and labor resources - Porto Alegre, RS, Brazil, 2017.

\begin{tabular}{|c|c|}
\hline Items & Mean \pm Standard deviation* \\
\hline \multicolumn{2}{|l|}{ Communication } \\
\hline Unbalanced patient assignment per professional & $2.60 \pm 0.923$ \\
\hline Inadequate hand-off from previous shift or sending unit & $2.29 \pm 0.931$ \\
\hline Other professionals did not provide the care needed (e.g. physiotherapist did not ambulate patient) & $2.64 \pm 1.089$ \\
\hline Lack of back up support from team members & $2.73 \pm 1.159$ \\
\hline Tension or communication breakdowns with other ancillary/support departments & $2.66 \pm 1.003$ \\
\hline Tension or communication breakdowns within the nursing team & $2.81 \pm 1.064$ \\
\hline Tension or communication breakdowns with the medical staff & $2.60 \pm 1.047$ \\
\hline Nursing assistant did not communicate that care was not done & $2.42 \pm 1.049$ \\
\hline Caregiver responsible off unit or unavailable & $2.77 \pm 1.086$ \\
\hline Total for dimension & $2.61 \pm 0.17$ \\
\hline \multicolumn{2}{|l|}{ Labor resources } \\
\hline Inadequate number of staff & $1.75 \pm 0.986$ \\
\hline Urgent patient situations & $1.69 \pm 0.882$ \\
\hline Unexpected rise in patient volume and/or activity in the unit & $1.57 \pm 0.858$ \\
\hline Inadequate number of care personnel (e.g. nursing assistants, technicians, unit secretaries etc.) & $1.76 \pm 0.892$ \\
\hline Heavy admission and discharge activity & $2.57 \pm 1.073$ \\
\hline Total for dimension & $1.87 \pm 0.40$ \\
\hline \multicolumn{2}{|l|}{ Material resources } \\
\hline Medications were not available when needed & $2.13 \pm 0.985$ \\
\hline Supplies/equipment not available when needed & $2.65 \pm 1.109$ \\
\hline Supplies/equipment not functioning properly when needed & $2.60 \pm 1.136$ \\
\hline Total for dimension & $2.46 \pm 0.29$ \\
\hline
\end{tabular}

* Scores: 1 (significant reason), 2 (moderate reason), 3 (minor reason), or 4 (not a reason for missed care). 
In the material resources category, supplies/equipment not functioning properly when needed was the most frequently cited as a moderate or significant reason for missed care (59\%). In the labor resources category, heavy admission and discharge activity, at 57.8\%, was the leading moderate or significant reason for missed care.

\section{DISCUSSION}

This study investigated missed nursing care in the context of care for patients with cancer. The findings revealed that nursing care items most often omitted were administration of medications, assistance with toileting, and attending patient calls. This shows that the nursing team faces certain difficulties with attending to patients rapidly, which could be influenced by several factors, ranging from the distance of patients' rooms to the nursing station to availability of materials and medication in the unit. Prioritization of certain needs may be related to overcrowding of hospitals, limited resources, and workload, among other factors ${ }^{(11-13)}$.

Another factor to be considered is that academic qualifications and experience in the area are both elements with a direct impact on the care provided to cancer patients ( $p=0.018$ and $p=0.046$, respectively), which has also been reported in a previous study ${ }^{(7)}$. On the other hand, the professional is usually allocated on the job according to the demand other than affinity with the area, which makes the bonding process more difficult, creating the necessity of a welcoming policy and proper training. The demands in areas in which professional suffering is significant can bring absenteeism and high turnover, damaging the dynamics and continuity of care ${ }^{(14)}$.

Working with cancer patients and families exposes the nursing team to a variety of sufferings, like death, long periods of intense coexistence, anger, stress, compassion fatigue and deterioration of important intimate relationships ${ }^{(14-15)}$.

The basic nursing care items in Dimension 2 that were most often missed were also identified in a study conducted in Mexico ${ }^{(16)}$, in which the most often missed care item was assistance with toileting needs within 5 minutes of request (57.8\%). A study conducted in the United States with 4086 nursing professionals providing intensive care in 10 hospitals reported a similar finding, with $48.6 \%$ of missed assistance with toileting needs within 5 minutes of request ${ }^{(17)}$.

One of the aspects of personal hygiene most valued by the members of the nursing team focuses on visible parts of the body, taking a perspective based on morality, decency, and good presentation. Nursing professionals understood the relationship between personal hygiene and nursing care as one of two interdependent concepts and emphasized hygiene as an important element in a professional's image and as an element of care essential to ensuring patient comfort and well-being ${ }^{(17)}$.

Furthermore, care with hygiene, and particularly patient bathing, provide a time for listening and interaction between nursing professionals and patients and for sharing knowledge and create an opportunity for assessment; so the act of bathing the patient can be seen as a vehicle for providing multiple items of nursing care, which enrich nurses knowledge and their value as carers. It is therefore of fundamental importance to rethink provision of this element of care, preserving direct care of the patient and providing care in a humanized manner in line with their requirements, and not merely through the nursing team simply acting to ensure hygiene, but taking the opportunity to provide the many different elements of care that can be delivered at this moment ${ }^{(18)}$.

The second item of care most often reported as missed by the nursing teams was ambulation three times per day or as ordered (44.6\%), although the participants pointed out that this element of care is provided by the physiotherapy team at the hospital studied. A similar finding was observed in a study conducted in Mexico, with $42 \%$ missed care reported $^{(16)}$; in a study conducted Turkey, which reported $42.2 \%$ omission $^{(17)}$, and in a study in Cyprus where the rate of missed ambulation three times per day was $49.1 \%{ }^{(19)}$.

In the United States, ambulation was also one of the principal items of missed care. The authors stated that less frequently missed items of care (vital signs, patient discharge planning and teaching, and glucose monitoring) are more likely to be noticed by other professionals when missed and are monitored by nursing managers. In contrast, ambulation is not an element of care that is routinely noted on patient charts and so there is less chance that other members of the team will realize it has been missed. In common with turning patients, ambulation demands considerable time and may require help from other professionals, who are not always available at the time ${ }^{(20)}$. It is possible that these elements of care are not seen as important by the nursing team, despite their strong associations with healthcare outcomes.

Turning patients every 2 hours was cited as missed by $36.1 \%$. Data on this care item was also reported in the study conducted in Mexico ${ }^{(21)}$, which assessed missed nursing care in patients at risk of pressure ulcers, finding a similar value to this study (31.1\%) for turning patients every 2 hours or as necessary. Another study, conducted with 32 patients and assessing the risk of development of pressure ulcers, identified risk factors among patients hospitalized in a clinical ward, and demonstrated that problems with turning patients could increase the risk of ulcers ${ }^{(21-22)}$. A study involving 157 nurses at inpatient oncology units reported that turning patients every 2 hours was a care item described as frequently or always missed $(66.9 \%)^{(19)}$.

With regard to administration of medications within 30 minutes before or after the scheduled time, $36.1 \%$ of the nursing team missed this care item. In Turkey, the rate of omission of this item was $21.6 \%^{(17)}$. A study conducted in a public hospital in Rio de Janeiro, Brazil, to identify the frequencies and types of intravenous medication errors found that late administration, which can affect the results of treatment and cause undesirable consequences for the patient, occurred in $69.75 \%$ of cases $^{(23)}$.

The least often missed care items, as reported by the nursing professionals, were capillary glucose monitoring (3.6\%), patient assessments performed each shift (6\%), IV/central line site care and assessments according to hospital policy 
(8.4\%), and fluid balance monitoring (9.6\%). Similar data were observed in a study in the United States with 586 nurses who reported capillary glucose monitoring and patient assessments performed each shift as rarely missed care items, at $81.6 \%$ and $67.9 \%$, respectively ${ }^{(24)}$.

The findings of the present study showed that the major reasons for not providing nursing care were related to communication. This contrasts with the findings of studies conducted in other countries. In Mexico, nurses stated that the principal factor that influenced missed care was nursing labor resources, followed by communication and then material resources in last place ${ }^{(16)}$. Along the same lines, a study in the United States identified labor resources as the principal category of reasons for missed care, with a mean of $80.67 \%$, while communication was the lowest rated category of reasons for missed care, at $65.16 \%{ }^{(20)}$. In Turkey, labor resources was also the most prevalent category of reasons for missed care, while communication had the least influence on missed nursing care ${ }^{(17)}$.

In the context of cancer care, communication is complex and permeated by the constant presence of anxiety about the future and the fear of death. Achieving effective communication involves interaction between many different professionals who must communicate in an interdisciplinary manner for the benefit of cancer patients ${ }^{(25)}$.

A study conducted to understand the views of these professionals on teamwork found that the virtues of humility and less bureaucratic hierarchical relationships with greater dialogue are fundamental to a healthy relationship and can be the decisive factors in working as a team ${ }^{(26)}$. This may offer an explanation for why the data collected in Brazilian settings differ from those from other countries, since working relationships tend to be hierarchical with little sharing. Therefore, the professionals identify tension and intra-team communication problems $(66.2 \%)$ as the principal reason for missed nursing care. In another study, while communication was not the principal category of reasons for omission, these items were cited by $78.9 \%$ of the professionals ${ }^{(17)}$.

In a study investigating leadership conducted with oncology nurses in a hospital in upstate Rio Grande do $\mathrm{Sul}$, interpersonal conflicts were cited as one of the most frequently encountered barriers to exercising team leadership, and were highlighted since it is inevitable that situations of conflict will occur, because of the diversity of profiles and personalities making up healthcare teams ${ }^{(27)}$. It has been pointed out that effective communication in the workplace may be capable of reducing conflicts and favors the formation of healthy professional relationships and so it is fundamental to adopt a posture based on dialogue to promote teamwork ${ }^{(26)}$.

Still within the communication category, another reason for missed care was that the caregiver responsible was off unit or unavailable (66.2\%). Two other important reasons, both with $60.2 \%$, were lack of back up support from team members and other professionals not providing the care needed (e.g. physiotherapist not ambulating the patient).

Cooperation in teamwork is expressed by the nursing team as availability to help a work colleague when there are difficulties with procedures. This cooperation may be between professionals from the same category, or between two different categories, whether for the construction of consensus or for complementarity in the technical dimension of care activities. Interdisciplinary teamwork is dependent on constitutional elements that determine its quality, such as communication, trust, mutual respect, and recognition, while conflict can be identified as an obstacle to integration and cooperation among professionals from the same team or different teams ${ }^{(28)}$.

A study conducted with nursing teams at three clinical and surgical units at three different hospitals tested the impact of an intervention on the level of job satisfaction in nursing teams and the quantity of missed care; which resulted in progress with team working and reductions in missed care over time, showing that satisfaction and knowledge about teamworking had increased after the intervention ${ }^{(6)}$.

In the category labor resources, heavy admission and discharge activity stands out with $57.8 \%$. It is worth pointing out that inadequate number of staff was only rated $16.8 \%$ and was one of the reasons least cited by participants. In contrast, a study conducted in Italy to adapt and validate the MISSCARE scale found that inadequate number of staff (85.5\%) was one of the top-ranked reasons for missed nursing care ${ }^{(28)}$. In Cyprus, nurses in oncohematological units reported that an inadequate number of staff had a major impact on missed nursing care (76.4\%), as did heavy admission and discharge activity $(57.3 \%)^{(19)}$.

There is a perception among nurses and supervisors that an inadequate number of staff has a direct influence on occurrence of adverse events, since low numbers and low quality of professionals, excessive workloads, and unfavorable conditions experienced by nurses restrict adequate implementation and management of healthcare. It has also been observed that sometimes the response to a lack of staff is focused merely on increasing the number of professionals, ignoring the element of the quality of the patient care provided by these professionals ${ }^{(29)}$.

One of the only studies using the MISSCARE instrument in an oncology setting was conducted in the United States and compared missed nursing care in inpatient oncology units with non-oncology units, finding that, in general, less care was missed in the inpatient oncology units ${ }^{(20)}$.

It is probable that the oncology nursing team prioritizes quality care higher than the professionals in clinical and surgical units because of the involvement in treatment and provision of individualized care ${ }^{(19,30)}$.

\section{CONCLUSION}

Missed nursing care is directly proportional to patient safety and is being widely discussed in many countries concerning the most varied contexts in attempts to use care indicators to assess which elements of nursing care are not being provided, in part or entirely, and the reasons why.

In our study, we found associations between basic nursing care and professionals' roles, their academic qualifications, and their experience, in which the elements of basic nursing care in Dimension 3 were cited as the most often 
missed. Additionally, reasons for missed care related to communication were the most prevalent. Communication is fundamental to provision of safe and high quality care to cancer patients and any failure in this process can result in adverse events, leading to serious consequences for patients and their families.
It is hoped that, despite the limited number of participants, the results of our study can be used in the development of nursing interventions that neutralize and/or reduce the negative results of missed care, improving the quality of care provided to oncology patients, strengthening nursing care, and contributing to the safety of hospital care.

\section{RESUMO}

Objetivo: Investigar a prevalência da falta do atendimento em enfermagem nas unidades de oncologia e suas causas. Método: Um estudo transversal foi conduzido em unidades oncológicas de internação em um hospital particular. Participaram 83 profissionais da equipe de enfermagem. O instrumento MISSCARE e um questionário sociodemográfico foram administrados. Foram usadas estatísticas descritivas simples para as análises. $\mathrm{O}$ teste qui-quadrado de Pearson foi usado para detectar as associações entre variáveis. Resultados: As tarefas de cuidado que faltaram mais frequentemente foi atender as necessidades de ir ao banheiro dentro de cinco minutos do pedido $(57,8 \%)$, deambulação três vezes por dia ou conforme solicitado $(44,6 \%)$ e virar o paciente a cada duas horas (36,1\%) As principais razões para essa falta de cuidado se relacionaram à comunicação: tensão ou rupturas na comunicação dentro da equipe de enfermagem e o responsável pelo atendimento estar fora da unidade ou indisponível (ambos 66,2\%). Conclusões: há uma necessidade de desenvolver intervenções de enfermagem que neutralizem e/ou reduzam os resultados negativos da falta de cuidado prestado aos pacientes com câncer.

\section{DESCRITORES}

Serviço Hospitalar de Oncologia; Cuidados de Enfermagem; Enfermagem Oncológica; Qualidade da Assistência à Saúde; Segurança do Paciente.

\section{RESUMEN}

Objetivo: Investigar la prevalencia de la falta de la atención en enfermería en las unidades de oncología y sus causas. Método: Un estudio transversal fue llevado a cabo en unidades oncológicas de estancia hospitalaria en un hospital privado. Participaron 83 profesionales del equipo de enfermería. El instrumento MISSCARE y un cuestionario sociodemográfico fueron administrados. Fueron utilizadas estadísticas descriptivas sencillas para los análisis. La prueba chi cuadrado de Pearson fue empleada a fin de detectar las asociaciones entre variables. Resultados: Las tareas de cuidado que faltaron más frecuentemente fue atender las necesidades de ir al baño dentro de cinco minutos del pedido (57,8\%), deambulación tres veces al día o conforme solicitado $(44,6 \%)$ y voltearle al paciente cada dos horas $(36,1 \%)$. Las principales razones para esa falta de cuidado se relacionaron con la comunicación: tensión o rupturas en la comunicación dentro del equipo de enfermería, y el responsable de la atención estar fuera de la unidad o indisponible (ambos el 66,2\%). Conclusiones: existe una necesidad de desarrollar intervenciones de enfermería que neutralicen y/o reduzcan los resultados negativos de la falta de cuidado prestado a los pacientes con cáncer.

\section{DESCRIPTORES}

Servicio de Oncología en Hospital; Atención de Enfermería; Enfermería Oncológica; Calidad de la Atención de Salud; Seguridad del Paciente.

\section{REFERENCES}

1. Bragadottir H, Kalisch BJ, Tryggvadottir GB. Correlates and predictors of missed nursing care in hospitals. J Clin Nurs. 2017;26(11-12):1524-34.

2. Brasil. Ministério da Saúde; Agência Nacional de Vigilância da Saúde. Incidentes Relacionados à Assistência à Saúde - 2015. Brasília: ANVISA; 2015.

3. World Health Organization. Patient safety, making health care safer. Geneva: WHO; 2017.

4. Minuzzi AP, Salum NC, Locks MOH, Amante LN, Matos E. Contributions of healthcare staff to promote patient safety in intensive care. Esc Anna Nery [Internet]. 2016 [cited 2018 May 12];20(1):121-9. Available from: http://www.scielo.br/scielo.php?script=sci_arttext\&pid $=\mathrm{S} 141481452016000100121 \& \operatorname{lng}=\mathrm{en} \& \mathrm{nrm}=$ iso

5. The Joint Commission. National Patient Safety Goals [Internet]. Oak Brook, Illinois; 2018 [cited 2018 May 12]. Available from: https:// www.jointcommission.org/standards_information/npsgs.aspx

6. Friese CR, Kalisch BJ, Lee KH. Patterns and correlates of missed nursing care in inpatient oncology units. Cancer Nurs [Internet]. 2013 [cited 2018 May 02]; 36(6):E51-7. Available from: https://www.ncbi.nlm.nih.gov/pmc/articles/PMC3577984/

7. Cho SH, Kim YS, Yeon KN, You SJ, Lee ID. Effects of increasing nurse staffing on missed nursing care. Int Nurs Rev [Internet]. 2015 [cited 2018 May 02];62(2):267-74. Available from: https://www.ncbi.nlm.nih.gov/pmc/articles/PMC3577984/

8. Siqueira LDC, Caliri MHL, Haas VJ, Kalisch B, Dantas RAS. Validation of the MISSCARE-BRASIL survey: a tool to assess missed nursing care. Rev Latino Am Enfermagem [Internet]. 2017 [cited 2018 June 04];25:e2975. Available from: http://www.scielo.br/scielo.php?script=sci_ arttext\&pid=S0104-11692017000100408

9. Siqueira LDC, Caliri MHL, Kalisch B, Dantas RAS. Cultural adaptation and internal consistency analysis of the MISSCARE Survey for use in Brazil. Rev Latino Am Enfermagem [Internet]. 2013 [cited 2018 June 04];21(2):610-7. Available from: http://www.scielo.br/pdf/rlae/ v21n2/0104-1169-rlae-21-02-0610.pdf

10. Brasil. Ministério da Saúde. Resolução n. 466, de 12 de dezembro de 2012. Dispõe sobre normas e diretrizes sobre pesquisas envolvendo seres humanos [Internet]. Brasília; 2012 [citado 2018 maio 02]. Disponível em: http://bvsms.saude.gov.br/bvs/saudelegis/cns/2013/ res0466_12_12_2012.html 
11. Assis YMS, Alves KYA, Santos VEP. Scientific evidence of nursing care and patient safety in oncology inpatient unit. Rev Cubana Enferm [Internet]. 2016 [cited 2018 June 04];32(3):1-17. Available from: http://www.medigraphic.com/pdfs/revcubenf/cnf-2016/cnf163p.pdf

12. Freitas JS, Silva AEBC, Minamisava R, Bezerra ALQ, Sousa MRG. Qualidade dos cuidados de enfermagem e satisfação do paciente atendido em um hospital de ensino. Rev Latino Am Enfermagem [Internet]. 2014 [cited 2018 June 04];22(3):454-60. Available from: http://www. scielo.br/scielo.php?script=sci_arttext\&pid=S0104-11692014000300454\&lng=en

13. Hernandez-Cruz R, Moreno-Monsiváis MG, Cheverría-Rivera S, Díaz-Oviedo A. Factors influencing the missed nursing care in patients from a private hospital. Rev Latino Am Enfermagem [Internet] 2017 [cited 2018 June 04]; 25:e2877. Available from: http://www.scielo. br/scielo.php?script=sci_arttext\&pid=S010411692017000100354\&lng=pt\&nrm=iso

14. Trindade LL, Bordignon M, Ferraz L, Amestoy SC. Professional satisfaction and quality of care in oncology: the vision of health professionals. Rev Online Pesq Cuid Fundam. 2015;7(2):2383-92.

15. Nolte AG, Downing C, Temane A, Hastings-Tolsma M. Compassion fatigue in nurses: a metasynthesis. J Clin Nurs. 2017;26(23-24):4364-78.

16. Moreno-Monsiváis MG, Moreno-Rodríguez C, Interial-Guzmán MG. Missed nursing care in hospitalized patients. Aquichan [Internet]. 2015 [cited 2018 May 02]; 15(3):318-28. Available from: http://www.scielo.org.co/scielo.php?script=sci_arttext\&pid $=$ S1657-59972015000300002

17. Kalisch BJ, Terzioglu F, Duygulu S. The MISSCARE Survey-Turkish: psychometric properties and findings. Nurs Econ. 2012;30(1):29-37.

18. Fonseca EF, Penaforte MHO, Martins MMFPS. Hygiene care - bath: meanings and perspectives of nurses. Rev Enferm Ref. 2015;5:37-45.

19. Papastavrou E, Dimitriadou M, Tsangari H, Andreou C. Nursing students' satisfaction of the clinical learning environment: a research study. BMC Nurs [Internet]. 2016 [cited 2018 May 02];15:44. Available from: https://www.ncbi.nlm.nih.gov/pmc/articles/PMC4949757/

20. Kalisch BJ, Tschannen D, Lee KH. Do staffing levels predict missed nursing care? Int J Qual Health Care. 2011;23(3):302-8.

21. Valles JHH, Monsivais MGM, Guzmán MGI, Arreola LV. Nursing care missed in patients at risk of or having pressure ulcers. Rev Latino Am Enfermagem [Internet]. 2016 [cited 2018 May 02]; 24(e2817). Available from: http://www.scielo.br/scielo.php?pid=S0104$11692016000100424 \&$ script $=$ sci_arttext\&tlng=pt

22. Quirino DES, Faustino AM, Freitas RO, Oliveira AB, Medved IV. Risk factors of developing pressure ulcers in a medical unit. Estima [Internet]. 2014 [cited 2018 May 02];12(4). Available from: https:/www.revistaestima.com.br/index.php/estima/article/view/99

23. Silva LD, Camerini FG. Analisys of intravenous medication administration in sentinel network hospital. Texto Contexto Enferm [Internet]. 2012 [cited 2018 May 02]; 21(3):633-41. Available from: http://www.scielo.br/scielo.php?script=sci_arttext\&pid=S0104-07072012000300019

24. Winsett RP, Rottet K, Schmitt A, Wathen E, Wilson D. Medical surgical nurses describe missed nursing care tasks: evaluating our work environment. Appl Nurs Res. 2016;32:128-33.

25. Bianchini D, Peuker A, C, Romeiro FB, Castro EK. A comunicação profissional-paciente em oncologia: uma compreensão psicanalítica. Psicol Estud. 2016;21(2):349-58.

26. Thofehrn MB, Montesinos MJL, Amestoy SC, Porto AR, Bettin AC, Fernandes HN, et al. Trabalho em equipe: visão de enfermeiros de um hospital de Murcia/Espanha. Enferm Glob [Internet]. 2014 [citado 2018 maio 02];(36):238-52. Disponível em: http://revistas.um.es/eglobal/ article/viewFile/190421/165731

27. Silva CN, Amestoy SC, Arriera ICO, Muniz RM, Baó ACP. Exercício da liderança do(a) enfermeiro(a) em unidades oncológicas. Rev Baiana Enferm [Internet]. 2016 [citado 2018 maio 02];30(2):1-10. Disponível em: https://portalseer.ufba.br/index.php/enfermagem/article/ viewFile/15173/pdf_47

28. Sist L, Contini C, Bandini A, Bandini S, Massa L, Zanin R, et al. MISSCARE Survey - Italian Version: findings from an Italian validation study. Ig Sanita Pubbl. 2017; 73(1):29-45.

29. Umpierrez AF, Fort ZF, Tomas VC. Adverse events in health and nursing care: patient safety from the standpoint of the professional's experience. Texto Contexto Enferm [Internet]. 2015 [cited 2018 May 02];24(2):310-5. Available from: http://www.scielo.br/pdf/tce/v24n2/ es_0104-0707-tce24-02-00310.pdf

30. Bordignon M, Monteiro MI, Mai S, Martins MFS, Rech CRA, Trindade LL. Oncology nursing professionals' job satisfaction and dissatisfaction in Brazil and Portugal. Texto Contexto Enferm [Internet]. 2015 [cited 2018 May 02]; 24(4):925-33. Available from: http://www.scielo.br/ scielo.php?script=sci_arttext\&pid=S0104-07072015000400925 